\title{
Eastern Orthodox Churches and Ecumenism according to the Holy Pan-Orthodox Council of Crete (2016)
}

\begin{tabular}{|c|c|}
\hline $\begin{array}{l}\text { Author: } \\
\text { luliu-Marius N }\end{array}$ & lorariu'1,2 \\
\hline $\begin{array}{l}\text { Affiliations: } \\
{ }^{1} \text { Faculty of Ort } \\
\text { Theology, Bab } \\
\text { University, Ror }\end{array}$ & $\begin{array}{l}\text { hodox } \\
\text { eş-Bolyai } \\
\text { nania }\end{array}$ \\
\hline $\begin{array}{l}{ }^{2} \text { Department } \\
\text { and Christian } \\
\text { of Theology ar } \\
\text { University of P } \\
\text { South Africa }\end{array}$ & $\begin{array}{l}\text { f Dogmatics } \\
\text { thics, Faculty } \\
\text { d Religion, } \\
\text { retoria, }\end{array}$ \\
\hline $\begin{array}{l}\text { Research Proj } \\
\text { Registration: } \\
\text { Project Leader } \\
\text { Project Numb }\end{array}$ & $\begin{array}{l}\text { ect } \\
\text { :T. van Wyk (D) } \\
\text { er: } 22153145\end{array}$ \\
\hline $\begin{array}{l}\text { Description: } \\
\text { Rev. Morariu i } \\
\text { in the researcl } \\
\text { 'Political Theo } \\
\text { by Dr Tanya va } \\
\text { Department o } \\
\text { and Christian } \\
\text { of Theology, U } \\
\text { Pretoria. }\end{array}$ & $\begin{array}{l}\text { participating } \\
\text { project, } \\
\text { logy', directed } \\
\text { n Wyk, } \\
\text { f Dogmatics } \\
\text { thics, Faculty } \\
\text { niversity of }\end{array}$ \\
\hline $\begin{array}{l}\text { Correspondin } \\
\text { luliu-Marius N } \\
\text { maxim@radio }\end{array}$ & $\begin{array}{l}\text { author: } \\
\text { lorariu, } \\
\text { renasterea.ro }\end{array}$ \\
\hline $\begin{array}{l}\text { Dates: } \\
\text { Received: } 03 \\
\text { Accepted: } 31 \\
\text { Published: } 10\end{array}$ & $\begin{array}{l}\text { Mar. } 2018 \\
\text { May } 2018 \\
\text { Sept. } 2018\end{array}$ \\
\hline $\begin{array}{l}\text { How to cite th } \\
\text { Morariu, I-M., } \\
\text { Orthodox Chur } \\
\text { Ecumenism ac } \\
\text { Holy Pan-Orth } \\
\text { Crete (2016)', } \\
\text { Studies/Theol } \\
74(4) \text {, a4954. } \\
\text { 10.4102/hts.v }\end{array}$ & $\begin{array}{l}\text { is article: } \\
2018, \text { 'Eastern } \\
\text { ches and } \\
\text { cording to the } \\
\text { odox Council of } \\
\text { tTS Teologiese } \\
\text { gical Studies } \\
\text { ttps://doi.org/ } \\
4 \mathrm{i} 4.4954\end{array}$ \\
\hline $\begin{array}{l}\text { Copyright: } \\
\text { (C) 2018. The A } \\
\text { Licensee: AOS } \\
\text { is licensed unc } \\
\text { Creative Comr } \\
\text { Attribution Lic }\end{array}$ & $\begin{array}{l}\text { uthors. } \\
\text { S. This work } \\
\text { ler the } \\
\text { nons } \\
\text { ense. }\end{array}$ \\
\hline Read online: & \\
\hline 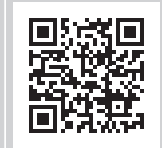 & $\begin{array}{l}\text { Scan this QR } \\
\text { code with your } \\
\text { smart phone or } \\
\text { mobile device } \\
\text { to read online. }\end{array}$ \\
\hline
\end{tabular}

Starting from the investigation of the documents issued by the Bishops who participated in the Holy Pan-Orthodox Council held in June 2016 in Crete, the author speaks in this research about the way in which ecumenism is understood from the perspective of this important event. The article tries to answer the question 'How did the event influence the Orthodox attitude towards ecumenism?' analysing documents, Mission of the Orthodox Church in Today's World and Relations of the Orthodox Church with the Rest of the Christian World, he shows that the dialogue entailed by ecumenism is perceived nowadays, according to the documents of the World Council of Churches, like a pilgrimage of justice and peace, and he highlights the main topics of this perception. Therefore, he shows that, according to the documents, a real and fruitful dialogue with other Christian faiths must be based on the Trinitarian witness, the Bible, the Tradition, the Creed and the teaching of the Seven Councils and that, among its main topics, one must definitely mention the witness, love, dialogue, the fight against discrimination or the care for the future of the Earth. The relevance of the ecclesiological background and of its understanding for the future of this dialogue is also mentioned. The documents are investigated in a deductive and comparative-analytic way by the author. If before the Council there was no official general attitude of the Orthodox space regarding ecumenism, nor an official document on this topic - although between 1968 and 1998 (the year when the Georgian and Bulgarian Orthodox Churches withdrew from the WCC), all the Orthodox Churches were members of the WCC - after this event, there is an official position and a list of main topics that could be developed and principles that should be respected for a fruitful dialogue in the future, at least for the Churches that took part in the Council. By analysing the aforementioned topics, by correlating them with other texts dedicated to the Council of Crete, and also by emphasising the perception of the Orthodox Church about ecumenical dialogue and its developments starting from the aforementioned event, the research brings into attention a sensitive topic and highlights some of its important, but not enough highlighted, aspects.

\section{Introduction}

Despite its controversial reception, the Holy Pan-Orthodox Council of Crete that took place in 2016 was an important event for the Eastern Orthodox space (Makrides 2017:7). Carefully prepared many years before (Getcha of Telmessos, Job 2017:274; Heneghan 2016:13-13; Ioniţă 2013,2016:9-10; Meimaris 2013:7), it was supposed to bring together to the table of debates all the Autocephalous Orthodox Churches in an attempt to solve some common problems inside Orthodoxy.

Shortly before the beginning, in a way that seemed to be predictable to many people (D'Aloisio 2016:3; Kattan 2016:11-15), the Bulgarian and Georgian Orthodox Churches, and also the Patriarchate of Alexandria, decided to cancel their presence at the event. They were soon followed by the Moscow and the Serbian Patriarchate, which later changed their decision and participated. Therefore, a planned Holy Pan-Orthodox Council for all the Eastern Orthodox Churches had fewer participants than some of its preliminary assemblies. The invocated reasons for the withdrawal were similar: big costs that the Churches could not afford to pay (Bulgarian Patriarchate; (Heller 2017:288), canonical problems between Patriarchates (Perşa 2017:131), the refusal to discuss some very important topics and the fear of fundamentalist attitudes (Morariu 2016:247), as well as the lack of unanimity in investigating some liturgical and theological topics (Jovic 2017:103). It is not the purpose of this article to present or to investigate them. Therefore, we will not insist on this topic. Nonetheless, we must mention that all the problems that preceded the Council and the withdrawal of the aforementioned Churches show once more that the EasternOrthodox space still needs to work on inter-orthodox dialogue and to fix its issues related to administration and authority before trying to analyse dogmatic topics and their challenges. 
Notwithstanding, despite these problems, through the decisions made, the debates held on topics like ecclesiology, bioethics (Morariu 2016:247-254) or ecumenism, and through the documents issued on its occasion, the meeting that took place in Crete between 16 and 27 June 2016 was an important moment for the history of the Orthodox Church that sends an interesting message and has positive echoes in other confessional spaces as well (Heller 2017:288-300; Thole 2017:27-38). Aware of these facts, we will try to investigate one of the important topics debated by the bishops who participated in the meetings, namely the relationships between the aforementioned Church and ecumenism and the manner in which this event contributed to their evolution and to answer the question: How did the event influence the Orthodox attitude towards Ecumenism? Before the Council, despite the participation of all Orthodox Churches in the WCC between 1968 (when the Serbian Orthodox Church joined) and 1998 (when the Bulgarian and Georgian Churches withdrew) and later on the participation of most Orthodox Churches, there was no document to establish the topics of dialogue with other Churches nor the main topics that should be debated with priority; this document is especially for the participant Churches and also for the entire Orthodox space, one that solves this problem offering keywords for future debates and the principles of a real and useful meeting with people of other faiths.

\section{Eastern Orthodox Churches and ecumenism according to the Holy Pan-Orthodox Council of Crete (2016)}

In its 6 sections (which were anticipated by the 10 sections proposed in the first preliminary assembly that took place between 21 and 26 November 1976 in Chambesy) (Ioniţă 2016:9-10), there is information about ecumenism in the parts dedicated to the relationship of Orthodox Churches with the rest of the Christian World (https:/ /www.holycouncil.org/-/ rest-of-christian-world, viewed 12 Jan. 2018) and in the section entitled 'The Mission of the Orthodox Church in Today's World' (https://www.holycouncil.org/-/mission-orthodoxchurch-todays-world, viewed 12 Jan. 2018). Sporadic references can also be found in some of the other sections.

But before speaking about these sections and trying to analyse the event from an ecumenical point of view, we consider it important to mention that some of the documents issued by the preliminary assemblies also deal with the topic of ecumenism, drafting already some of the future documents of the Council of Crete. Therefore, for example, the documents of the assembly that took place in October 2015 in Chambesy, in a text that looks similar to some of the documents of the Second Vatican Council (Burigana 2015:415; http://www. vatican.va/archive/hist_councils/ii_vatican_council / documents/vat-ii_decree_19641121_unitatis-redintegratio_ po.html, viewed 12 Jan. 2018) mentioned the fact that:

The Orthodox Church, which unceasingly prays 'for the union of all', has always promoted dialogue with those separated from her, both far and near, playing a leading role in seeking ways and means to restore the unity of believers in Christ, participating in the ecumenical movement since its inception, and contributing to its formation and further development. (The Ecumenical Patriarchate 2016:305)

Subsequently, after speaking about unity as a task of Orthodoxy and mentioning the efforts made by its members towards its achievement, they also pointed to the following:

... for theological and pastoral reasons, she (the Orthodox
Church) has been favourably disposed to dialogue with various
Christian Churches and confessions, and to participation in the
present-day ecumenical movement in general, in the belief that
she thus bear active witness to the plenitude of Christ's truth and
her spiritual treasures before those who are external to her and
are pursuing an objective goal - to tread the path of unity.
(Ecumenical Patriarchate 2016:306)

We would like to insist on the fact that this is only one of the documents that speak about ecumenism and that in most of the documents of the preliminary assemblies, ecumenism is mentioned when the authors speak either about unity and its relevance or about the mission and relationships of the Orthodox Church with other spaces.

In the aftermath of the Council, ecumenism and the relevance of the ecumenical participation of the Orthodox Churches are, as we have already mentioned, very clearly emphasised. The first document that speaks about this topic is the one dedicated to the relationship of the aforementioned churches with mission (https://www.holycouncil.org/-/missionorthodox-church-todays-world, viewed 30 Jan. 2018). Besides some attempts made by theologians like Nikos Nissiotis (1961a:3-27; 1961b:121-131; 1961c:1-12; 1961-1962:22-52; 1962:192-202; 1985:326-335) and Ioan Bria (1996) and besides a few paragraphs from the social document of the Russian Orthodox Church (Constantineanu et al. 2016:75; Ică \& Marani 2002:186-268), this is, according to specialists, the first important Orthodox document on mission (Vassiliadis 2016:352). Criticised by some theologians for its old-fashioned language (Voulgaraki-Pissina 2017:144), sanctioned as being a compilation of two older documents already drafted during the preliminary assemblies of the Council (Heller 2017:293294) or praised by others, it remains one of the important documents of contemporary Orthodox theology.

After an introductory part where the authors speak about the necessity of an active implication of the Church in contemporary problems, ${ }^{1}$ the emphasis is moved towards the necessity of justice and peace. In a way that makes its content similar to the WCC document, An Ecumenical Call to

1.Finding constant inspiration in this expectation and foretaste of the Kingdom of God, the Church cannot remain indifferent to the problems of humanity in each period. On the contrary, she shares in our anguish and existential problems, taking upon herself - as the Lord did - our suffering and wounds, which are caused by upon herself - as the Lord did - our suffering and wounds, which are caused by evil in the world and, like the Good Samaritan, pouring oil and wine upon our wounds through words of patience and comfort ( $\mathrm{Rm}$ 15:4; Heb 13:22), and through love in practice. The word addressed to the world is not primarily mean to judge and condemn the world (cf. In $3: 17 ; 12: 47$ ), but rather to offer to the world the guidance of the Gospel of the Kingdom of God - namely, the hope an assurance that evil, no matter its form, does not have the last word in history and must not be allowed to dictate its course. (https://www.holycouncil.org/-/ mission-orthodox-church-todays-world, viewed 30 Jan. 2018) 
Just Peace (http: / / www.overcomingviolence.org/fileadmin/ dov / files / iepc/resources / ECJustPeace_English.pdf, accessed 30.01.2008), highlighting the topics of 'love', 'world' and 'Church' as key concepts (Bargár 2017:391; *** The Mission of the Orthodox Church in Today's World 2016:344), the drafters show that:

The Orthodox Church has diachronically recognized and revealed the centrality of peace and justice in people's lives. The very revelation of Christ is characterized as a gospel of peace (Eph 6:15), for Christ has brought peace to all through the blood of his Cross (Col 1:20), preached peace to those afar and near (Eph 2:17), and has become our peace (Eph 2:14). This peace, which surpasses all understanding (Phil 4:7), as the Lord Himself told His disciples before His passion, is broader and more essential than the peace promised by the world: peace I leave with you, my peace I give to you; not as the world gives do I give to you (Jn 14:27). This is because the peace of Christ is the ripe fruit of the restoration of all things in Him, the revelation of the human person's dignity and majesty as an image of God, the manifestation of the organic unity in Christ between humanity and the world, the universality of the principles of peace, freedom, and social justice, and ultimately the blossoming of Christian love among people and nations of the world. The reign of all these Christian principles on earth gives rise to authentic peace. It is the peace from above, for which the Orthodox Church prays constantly in its daily petitions, asking this of the almighty God, Who hears the prayers of those that draw near to Him in faith. (https: / / www. holycouncil.org/-/mission-orthodox-church-todays-world, viewed 30 Jan. 2018)

The Christological dimension of ecumenical dialogue is the point of departure for ecumenical dialogue, and this is clearly stipulated from the beginning of the document that later links it to the Trinitarian confession and to its ecclesiological implications. The bishops who drafted the document gave it and its pragmatic outcomes, such as peace and love understood in the acceptation of Christ, an important role.

Summarising the six relevant topics that are relevant for mission, namely the dignity of the human person, freedom and responsibility, peace and justice, aversion to war, the attitude towards discrimination and the witnessing of love (Bargár 2017:391), and the linking of love and responsibility, ${ }^{2}$ the authors of these topics offer in a rather simple way maybe to avoiding the disagreement of some Churches like the Russian Orthodox one that was not present (Bouteneff 2016:10) - but still in an interesting way, an intriguing presentation of the Orthodox theology of the mission. Because of its understanding as love, responsibility and fight for justice and peace, this part of the conciliar decision is also important in the process of understanding the role of the Orthodox Church in the ecumenical dialogue.

However, without a doubt, the most complex document where information about ecumenism can be found is the

2.Because: 'Freedom is introduced as one of God's greatest gifts to humankind (MOCT B.1). However, if people are to enjoy it on a long-term basis, freedom needs to go hand in hand with responsibility' (Bargár 2017:392). one dedicated to the relationship of the Orthodox Churches with the rest of the Christian world (https://www. holycouncil.org/-/ rest-of-christian-world, accessed 30.01.2018). Its content, assumed by the participants, is strongly focused on the idea of dialogue for unity. Underlining this main aspect, the Ecumenical Patriarch Bartholomew of Constantinople would say during his visit at the General Secretariat of the WCC of Geneva, on 24 April 2017:

We Orthodox strongly believe that the aim and the raison d'être of the Ecumenical Movement and of the World Council of Churches is to fulfil the Lord's final prayer, that 'all may be one' (Jn 17:21), which is inscribed on the beautiful tapestry ornamenting the wall of this hall. (Editorial Ecumenical Chronicle 2017:437)

This document, more than others from the same meeting, emphasises not only the relevance of the promotion of Christian Unity $^{3}$ but also the link between this topic and the ecumenical engagement of the Orthodox Church. Therefore, as the authors say:

The Orthodox Church, which prays unceasingly 'for the union of all', has always cultivated dialogue with those estranged from her, those both far and near. In particular, she has played a leading role in the contemporary search for ways and means to restore the unity of those who believe in Christ, and she has participated in the Ecumenical Movement from its outset, and has contributed to its formation and further development. Moreover, the Orthodox Church, thanks to the ecumenical and loving spirit which distinguishes her, praying as divinely commanded that all men may be saved and come to the knowledge of the truth (1 Tm 2:4), has always worked for the restoration of Christian unity. Hence, Orthodox participation in the movement to restore unity with other Christians in the One, Holy, Catholic and Apostolic Church is in no way foreign to the nature and history of the Orthodox Church, but rather represents a consistent expression of the apostolic faith and tradition in a new historical circumstances. (https://www.holycouncil.org/-/rest-of-christian-world, viewed 30 Jan. 2018)

The commandment of love that comes as a request from Christ is, therefore, the basis of ecumenical dialogue. The authors of the document highlight this showing that a form of its accomplishment can be seen in the dialogue with people from other faiths. The document also emphasises the witnessing dimension of the Orthodox presence in the Orthodox Churches from the ecumenical space.

The document also emphasises very well the relevance of ecclesiology in the dialogue for unity (Ioja 2016:8), which is the heart of each confession. Also, in a way that feeds from the approaches of the documents issued by the WCC (like *** Baptism, Eucharist and Ministry [BEM] 1982) or Who Do We Say That We Are? (*** Who Do We Say That We Are? Christian Identity in a Multi-Religious World 2016), the bishops who have issued this document specify the elements that

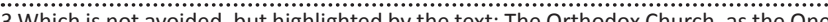
Holy, Catholic, and Apostolic Church, in her profound ecclesiastical selfconsciousness, believes unflinchingly that she occupies a central place in the matter consciousness, believes unflinchingly that she occupies a central place in the matter
of the promotion of Christian unity in the world today. (https://www.holycouncil. org/-/rest-of-christian-world, accessed 30.01.2018) 
constitute the basis of the aforementioned dialogue, namely truth, faith, the tradition and the Seven Ecumenical Councils. ${ }^{4}$

Later on, the same document speaks about the participation of the Orthodox Church in the WCC. The authors highlight the fact that:

The Orthodox Churches that are members of the WCC regard as an indispensable condition of their participation in the WCC the foundational article of its Constitution, in accordance with which its members may only be those who believe in the Lord Jesus Christ as God and Savior in accordance with the Scriptures, and who confess the Triune God, Father, Son, and Holy Spirit, in accordance with the Nicene-Constantinopolitan Creed. It is their deep conviction that the ecclesiological presuppositions of the 1950 Toronto Statement (http://www.oikoumene.org/en/ resources/documents / central-committee/1950/torontostatement, viewed 30 Jan. 2018), On the Church, the Churches and the World Council of Churches, are of paramount importance for Orthodox participation in the Council. It is therefore very clear that the WCC does not by any means constitute a 'super-Church'.

The purpose of the World Council of Churches is not to negotiate unions between Churches, which can only be done by the Churches themselves acting on their own initiative, but to bring Churches into living contact with each other and to promote the study and discussion of the issues of Church unity. No Church is obliged to change her ecclesiology on her accession to the Council ... Moreover, from the fact of its inclusion in the Council, it does not ensue that each Church is obliged to regard the other Churches as Churches in the true and full sense of the term. (Toronto Statement, § 2). (https://www.holycouncil.org/-/restof-christian-world, viewed 30 Jan. 2018)

Therefore, according to the document, the role of the World Council of Churches and the relationship of the Orthodox Churches are clearly defined in accordance with the Orthodox doctrine and with the documents issued by the ecumenical institution. Confirming the fact that the purpose of the WCC is not to be the founder of a space of syncretism, as some of the fundamentalist voices from the Orthodox space accuse, the bishops of the Council show that its purpose is to create a space for meeting, discovering, debating and understanding the others. Its impartiality is highlighted by the fact that it doesn't even force 'the other Churches as Churches in the true and full sense of the term'. Of course, the Trinitarian basis of the WCC and its Christological main point, manifested in the recognition of Christ's divinity and of his role as a Saviour, are important tasks that contribute to dialogue, creating bridges and starting points of debate. Through these explanations, the bishops who participated in the Council of Crete try to present in a deeper and clearer

4.The contemporary bilateral theological dialogues of the Orthodox Church and he participation in the Ecumenical Movement rest on this self-consciousness of Orthodoxy and her ecumenical spirit, with the aim of seeking the unity of all Christians on the basis of the truth of the faith and tradition of the ancient Church of the Seven Ecumenical Councils (https://www.holycouncil.org/-/rest-of-christianworld, viewed 30 Jan. 2018). They develop this point and later mention in the document that: Remaining faithful to her ecclesiology, to the identity of her internal structure, and to the teaching of the ancient Church of the Seven Ecumenical Councils, structure, and to the teaching of the ancient Church of the Seven Ecumenical Councils, the Orthodox Church's participation in the WCC does not signify that she accepts the notion of the 'equality of Confessions', and in no way is she able to accept the unity of the Church as an inter-confessional compromise. In this spirit, the unity that is sough within the WCC cannot simply be the product of theological agreements, but must also be founded on the unity of faith, preserved in the sacraments and lived out in the Orthodox Church (https://www.holycouncil.org/-/rest-of-christian-world, viewed 30
Jan. 2018). way ecumenism and its relationship with the Orthodox Church and to answer, at the same time, the unjustified accusation coming from the fundamentalist side.

After speaking also about the possibility of developing some points of dialogue and about common points of acting in the Christian space (some of them, like bioethics topics (Morariu 2016:247-254) or ecology or technology, would also be developed in other documents from the same Council), the author refers to the suspicion developed by some of the new forms of ecumenical dialogue. Therefore, it is mentioned that:

The Orthodox Church is aware that the movement to restore Christian unity is taking on new forms in order to respond to new circumstances and to address the new challenges of today's world. The continued witness of the Orthodox Church to the divided Christian world on the basis of the apostolic tradition and faith is imperative. (https://www.holycouncil.org/-/restof-christian-world, viewed 30 Jan. 2018)

In a nutshell, these would be the main points of the documents of the Holy Pan-Orthodox Council of Crete that speak about ecumenism and about the relationships of the Orthodox Church with other confessional spaces. As we can see, although there are some points that could definitely be developed further on, the topic is not avoided by the participants and, according to the documents, there are many possibilities for dialogue in the pilgrimage of justice and peace.

\section{Conclusion}

Through practical aspects, like the participation of delegates from other churches in the event (e.g. the Catholic Church was represented by Cardinal Kurt Koch, the director of the Pontifical Office for Dialogue with Other Christians, and by Bishop Brian Farell from the same office [Farell 2017:87], and also by other representatives from other confessional spaces), and by using theological arguments, the Holy Pan-Orthodox Council of Crete offers, mostly in two of its documents, the one dedicated to mission and the one dedicated to the relationships with the rest of the Christian World, interesting information about the way in which the ecumenical dialogue with other Christians can be developed, about the way it can be pursued, as a pilgrimage of justice and peace, in accordance with the documents of the WCC following the Busan assembly of 2013. The documents also offer keywords for the understanding of these relationships and of their development, such as love, witness, fight against discrimination, ecological crisis or diaconia; it also states documents like the ones of the Seven Ecumenical Councils, the Nicaea-Constantinopolitan creed or elements like the Scripture or the tradition at the basis of a truly fruitful dialogue.

Because of the importance of the event for the Orthodox space and of the lack of papers that describe the Orthodox understanding of ecumenism, the contribution of the Orthodox Church to ecumenism, the principles of the orthodox Church and the main topics that, according to her doctrine, can be debated, the Council and its outcomes, namely the documents 
it issued and in particular the ones we investigated in this paper, offer both a valuable and interesting theological evidence and a programme for the future development of ecumenical dialogue from an Orthodox perspective.

In conclusion, it can be said that, without betraying the Orthodox faith and by expressing the concern that some modern understandings of ecumenical dialogue could be a 'stumbling stone' in the future of dialogue for unity and reconciliation, the authors of the documents issued by the aforementioned council speak about unity as a task of the Orthodox Church, emphasising the relevance of ecclesiology, witnessing its achievement and highlighting the dimension of pilgrimage towards its unity.

\section{Acknowledgements Competing interests}

The author declares that he has no financial or personal relationships which may have inappropriately influenced him in writing this article.

\section{References}

Bargár, P., 2017, 'Pondering "the mission of the orthodox church in today's world" A protestant missiological reflection', International Review of Mission 106(2), 389-399. https://doi.org/10.1111/irom.12193

Bouteneff, P., 2016, 'Great and Holy Council', Christian Century 133(20), 10-12.

Bria, I., 1996, The liturgy after the liturgy, WCC Publications, Geneva.

Burigana, R., 2015, 'Solo cinquant'anni ... Note sul decreto Unitatis Redintegratio del Vaticano II e sulla recezione (1964-2014)', Studia Ecumenica 33(3-4), 415-432.

Constantineanu, C., Măcelaru, M.V., Kool, A.-M. \& Himcinschi, M. (eds.), 2016, Mission in Central and Eastern Europe. Realities, perspectives, trends, Regnum Books International, Oxford.

D’Aloisio, C., 2016, 'En attendant les fruits du Concile du Crète', Le Messager Orthodoxe 2(161), 3-10.

Editorial, 2016, 'The mission of the Orthodox church in today's world', International Review of Mission 105(2 (403), 324-355.

Editorial, 2017, 'Ecumenical Chronicle', Ecumenical Review 59(3), 436-441.

Farell, B., 2017, 'Report on the activities of the pontifical council for promoting Christian unity during 2016', Catholica 71(2), 87-98.

Getcha of Telmessos, Job, 2017, 'The ecumenical significance of the Holy and Great Council of the Orthodox Church', The Ecumenical Review 69(2), 274-287. https:// doi.org/10.1111/erev.12288

Heller, D., 2017, 'The (Holy and Great) Council of the Orthodox churches: An ecumenical perspective', The Ecumenical Review 69(2), 288-300. https://doi. org/10.1111/erev.12289
Heneghan, T., 2016, 'Orthodox leaders hold historic council', Christian Century 133(15), 12-13.

Ică jr, I. \& Marani, G., 2002, Gândirea socială a Bisericii. Fundamente- documenteanalize-perspective, Editura Deisis, Sibiu.

Ioja, C., 2016, 'The Holy and Great Synod - Sinodality and co-responsibility in the current world', Teologia 68(3), 7-8.

Ioniţă, V., 2013, Hotărârile întrunirilor panortodoxe din 1923 până în 2009 - spre Sfântul şi Marele Sinod al Bisericii Ortodoxe, Editura Basilica a Patriarhiei Române, Bucureşti.

Ioniţă, V., 2016, Sfântul şi Marele Sinod al Bisericii Ortodoxe - documente pregătitoare, Editura Basilica, Bucureşti.

Jovic, R., 2017, 'The importance of fasting and its observance for tomorrow', Studia Universitatis Babeş-Bolyai - Series Theologiy Orthodoxa 1(62), 103-114. https:// doi.org/10.24193/subbto.2017.1.07

Kattan, A.E., 2016, 'Le concile de Crète: en espérant que nous apprenions', Le Messager Orthodoxe 2(161), 11-15.

Makrides, V.N., 2017, 'Le concile panorthodoxe de 2016. Quelques réflexions sur les défis auxquels le monde orthodoxe doit faire face', Istina 72(1), 5-26.

Meimaris, T.A., 2013, The Holy and Great Council of the Orthodox Church \& the ecumenical movement, Ant. Stamoulis Publications, Thesaloniki.

Morariu, I.-M., 2016, 'Bioethics in the discussions of the pan-Orthodox synod from Crete (2016)', Astra Salvensis 4(7), 247-254.

Nissiotis, N., 1962, 'The witness and the service of Eastern Orthodoxy to the one undivided Church', The Ecumenical Review 14(2), 192-202. https://doi. org/10.1111/j.1758-6623.1962.tb02001.x

Nissiotis, N., 1985, 'Towards a new ecumenical era', The Ecumenical Review 37(3), 326-335. https://doi.org/10.1111/j.1758-6623.1985.tb01323.x

Nissiotis, N.A., 1961-1962, 'Ecclesiological foundation os mission from the Orthodox Point of view', The Greek Orthodox Theological Review 7(1-2), 22-52.

Nissiotis, N.A., 1961a, 'Interpreting orthodoxy', The Ecumenical Review 14(1), 3-27. https://doi.org/10.1111/j.1758-6623.1961.tb01981.x

Nissiotis, N.A., 1961b, 'Les Eglises d'Europe et le Monde - Fondement de la mission universelle', Contacts 13(33), 121-131.

Nissiotis, N.A., 1961c, 'The ecclesiological significance of interchurch Diakonia', The Ecumenical Review 13(2), 1-12. https://doi.org/10.1111/j.1758-6623.1961. tb01934.x

Perşa, R., 2017, 'A canonical analysis of the most controversial phrase of the Holy and Great Council: "The Orthodox Church accepts the historical name of other non-Orthodox Christian churches and confessions that are not in communion with her"', Studia Universitatis Babes-Bolyai - Series Theologiy Orthodoxa 1(62) 131-157. https://doi.org/10.24193/subbto.2017.1.09

The Ecumenical Patriarchate, 2016, 'Relations of the Orthodox Church with the rest of the Christian world draft document of the Pan-Orthodox Council, Adopted by the 5th Pan-Orthodox Pre-Council Conference in Chambesy 10-17 October 2015', The Ecumenical Review 68(2-3), 305-311.

Thole, R., 2017, 'Le Saint et grand Concile de l'Eglise orthodoxe (Crète, 2016) entre épreuve et promesse. Un écho luthérien', Istina 62(1), 27-38.

Vassiliadis, P., 2016, 'A preliminary short comment', International Review of Mission 105(2), 352-355.

Voulgaraki-Pissina, E., 2017, 'Reading the document on mission of the Holy and Great Council from a missiological point of view', International Review of Mission 106(1), 136-150. https://doi.org/10.1111/irom.12172

World Council of Churches 1982, Baptism, Eucharist and Ministry, World Council of Churches, Geneva.

World Council of Churches (ed.), 2016, Who do we say that we are? Christian identity in a multi-religious world, World Council of Churches Publications, Geneva. 